\title{
PENGARUH KUALITAS PRODUK, CITRA MEREK, DAN PERSEPSI HARGA TERHADAP KEPUTUSAN PEMBELIAN MASKER SENSI DI TANGERANG
}

\author{
Dea Aurani Qiana dan Yenny Lego \\ Program Studi Manajemen Fakultas Ekonomi Universitas Tarumanagara, Jakarta \\ Email: \\ deaaurani@gmail.com \\ yennyl@fe.untar.ac.id
}

\begin{abstract}
The purpose of this study is to examine the effect of product quality, brand image, and price perception toward purchase decision of Sensi Masks in Tangerang. The sampling method in this study was purposive sampling. The sample in this study are 100 Sensi masks customers in Tangerang by distributing questionnaires online using Google Form. The data were processed using SmartPLS v.3.2.2. The results of this study indicate that product quality has a significant positive effect on purchase decision, brand image has a significant positive effect on purchase decision, and price perception has a significant positive effect on purchase decision.
\end{abstract}

Keywords: Product Quality, Brand Image, Price Perception, Purchase Decision.

Abstrak: Tujuan dari penelitian ini adalah untuk menguji pengaruh kualitas produk, citra merek, dan persepsi harga terhadap keputusan pembelian masker Sensi di Tangerang. Metode pengambilan sampel pada penelitian ini adalah purposive sampling. Sampel pada penelitian ini sebanyak 100 konsumen masker Sensi di Tangerang dengan menyebarkan kuesioner daring melalui Google Form. Data penelitian ini diolah menggunakan SmartPLS v.3.2.2. Hasil dari penelitian ini menunjukkan bahwa kualitas produk memiliki pengaruh positif yang signifikan terhadap keputusan pembelian, citra merek memiliki pengaruh positif yang signifikan terhadap keputusan pembelian, dan persepsi harga memiliki pengaruh positif yang signifikan terhadap keputusan pembelian.

Kata Kunci: Kualitas Produk, Citra Merek, Persepsi Harga, Keputusan Pembelian.

\section{LATAR BELAKANG}

Pada dewasa ini jumlah dari populasi masyarakat dunia sangatlah besar dan akan terus bertambah seiring dengan berjalannya waktu. Indonesia merupakan negara dengan populasi terpadat keempat di dunia. Menurut sensus penduduk yang dilakukan oleh Badan Pusat Statistik (BPS) pada September tahun 2020, Indonesia memiliki total populasi penduduk sebanyak 270,2 juta jiwa. Total penduduk yang besar tersebut berpengaruh terhadap kebutuhan penduduk mulai dari kebutuhan sandang, pangan, dan papan. Banyak industri berdiri untuk memenuhi kebutuhan penduduk, seperti industri tekstil, makanan, minuman, dan transportasi. 
Salah satu yang berkontribusi dalam meningkatkan polusi udara adalah kendaraan. Volume kendaraan yang banyak dan terus meningkat serta tidak diikuti dengan ketersediaan lingkungan hijau yang mencukupi di suatu kawasan membuat masyarakat harus mengambil langkah yang lebih preventif untuk menghindari polusi udara. Salah satu cara yang dapat dilakukan untuk mengurangi dampak polusi adalah dengan menggunakan masker. Kehadiran masker sangat membantu untuk melindungi masyarakat dari polusi udara, debu, dan virus. Masker juga penting digunakan pada orang yang sedang sakit untuk mencegah penyebaran virus kepada orang lain.

Banyaknya produsen masker yang muncul dan berkembang, menuntut Sensi untuk memberikan kualitas produk yang lebih baik. Berdasarkan beberapa penelitian sebelumnya seperti yang dilakukan oleh Fatmawati dan Soliha (2017) menemukan bahwa keputusan pembelian pelanggan dipengaruhi oleh kualitas produk, citra merek dan persepsi harga. Kualitas produk masker sangatlah penting terlebih di masa pandemi virus COVID-19 agar dapat menghindari penularan virus dari satu individu ke individu lainnya. Masker Sensi memiliki kualitas yang baik, walaupun masih memiliki kekurangan seperti lapisan masker yang dirasa terlalu tebal dan terkadang menyulitkan pengguna untuk bernafas saat digunakan beraktivitas, terlebih saat digunakan di cuaca yang panas. Masker Sensi memiliki tali yang terasa kurang nyaman di telinga saat digunakan. Ketahanan masker Sensi di luar ruangan dirasa kurang, masker Sensi hanya bertahan beberapa jam saja untuk penggunaan luar ruangan dengan kegiatan yang berat, seperti berolahraga dan kegiatan konstruksi. Sehingga harus membawa masker yang baru untuk mengganti masker Sensi yang sudah tidak layak pakai. Masker Sensi juga harus disimpan dengan baik, karena bahan masker Sensi mudah sekali kusut jika disimpan di saku atau di dalam tas.

Citra masker Sensi adalah masker yang dapat dipercaya untuk menyaring udara dan virus untuk kegiatan sehari - hari, sampai penggunaan untuk operasi bedah. Citra merek masker Sensi kurang baik setelah terjadinya kelangkaan pada masa pandemi virus Covid-19, karena naikan harga yang tidak wajar membuat masker Sensi memiliki citra masker yang sulit untuk dijumpai di pasaran dan tidak ekonomis dengan kenaikan harga yang tidak wajar. Kenaikan harga tersebut disebabkan oleh kelangkaan masker Sensi di pasaran dan penimbunan yang dilakukan oleh pihak tertentu untuk dijual kembali. Hal tersebut mengakibatkan masyarakat beralih menggunakan masker kain yang sesuai dengan anjuran WHO (World Health Organization) dan masker medis merek lainnya yang dirasa lebih ekonomis dan memiliki citra merek yang baik.

Konsumen menganggap bahwa harga yang ditawarkan oleh Sensi relatif terjangkau sesuai dengan kualitas yang dimilliki oleh masker Sensi. Hal ini berubah saat masa pandemi Covid-19 yang terjadi di awal tahun 2020, di mana harga masker Sensi meningkat tajam dengan sangat tidak wajar yang disebabkan oleh kelangkaan masker Sensi di pasaran. Kelangkaan masker Sensi di pasaran diakibatkan oleh meningkatnya permintaan terhadap masker Sensi yang digunakan untuk mencegah penyebaran virus Covid-19 saat beraktivitas. Kenaikan harga masker Sensi juga disebabkan oleh adanya penimbunan masker yang dilakukan pihak tertentu untuk dijual kembali dengan harga yang lebih tinggi. Sehingga dari kenaikan harga yang dirasa tidak wajar tersebut masyarakat merasa bahwa harga yang ditawarkan untuk masker Sensi relatif mahal dan tidak lagi sesuai dengan manfaat atau kegunaan masker Sensi.

Berdasarkan uraian tersebut, persoalan yang perlu dikaji dalam penelitian ini, yaitu: 1). Apakah terdapat pengaruh positif kualitas produk terhadap keputusan pembelian masker Sensi di Tangerang? 2). Apakah terdapat pengaruh positif citra merek terhadap keputusan pembelian masker Sensi di Tangerang? 3). Apakah terdapat pengaruh positif persepsi harga terhadap 
keputusan pembelian masker Sensi di Tangerang? Hasil dari penelitian ini diharapkan dapat memberikan kontribusi kepada produsen masker Sensi untuk mengetahui variabel yang memiliki pengaruh terbesar terhadap keputusan pembelian seorang konsumen.

\section{KAJIAN TEORI}

\section{Kualitas Produk}

Menurut Kotler dan Armstrong (2011, p. 230) kualitas produk adalah "characteristics of a product or service that bear on its ability to satisfy stated or implied customer needs". Ulaga (2003) menyatakan bahwa kualitas produk adalah sejauh mana produk pemasok dapat memenuhi spesifikasi yang dimiliki oleh konsumen. Hafilah, Chaer, dan Usman (2019) menyatakan bahwa kualitas produk adalah kapasitas kinerja suatu produk sesuai dengan fungsinya yang meliputi daya tahan, keandalan, kemudahan pengoperasian, dan tingkat akurasi serta atribut berharga lainnya.

Dari seluruh definisi di atas, maka dapat ditarik kesimpulan bahwa kualitas produk adalah manfaat yang dirasakan atas suatu produk sesuai dengan ekspetasi yang dimiliki oleh konsumen sebelum menggunakan produk tersebut.

\section{Citra Merek}

Citra merek menurut Ida dan Hidayati (2020) adalah sebuah gambaran atau impresi yang dihasilkan oleh suatu merek di dalam benak konsumen. Menurut Hafilah, et al. (2019) citra merek adalah representasi dari keseluruhan persepsi dari sebuah merek dan terbentuk dari informasi dan pengalaman terhadap merek tersebut. Kotler dan Keller (2009, p. 286) menyatakan citra merek sebagai "The perceptions and beliefs held by consumers, as reflected in the associations held in consumer memory".

Berdasarkan definisi di atas, maka dapat ditarik kesimpulan bahwa citra merek adalah gambaran yang dimiliki oleh seseorang saat melihat atau mendengar suatu merek berdasarkan pada informasi dan pengalamannya.

\section{Persepsi Harga}

Persepsi harga menurut Peter dan Olson (2009, p. 447) adalah "How price information is comprehended by consumers and made meaningful to them". Campbell (1999, p. 187) mengidentifikasikan persepsi harga "as one psychological factor that exerts an important influence on consumers' reactions to prices". Zietsman, Mostert dan Svensson (2018) mendefinisikan persepsi harga sebagai penilaian objektif yang dimiliki oleh konsumen tentang kewajaran harga suatu produk atau jasa dibandingkan dengan harga kompetitor.

Dari seluruh definisi di atas, maka dapat ditarik kesimpulan bahwa persepsi harga adalah pandangan seorang konsumen terhadap harga dari suatu barang atau jasa sebanding dengan manfaat yang akan dirasakan.

\section{Keputusan Pembelian}

Schifman dan Kanuk (2000, p. 437) mendefinisikan keputusan pembelian "The selection of an option from two or alternative choice". Schiffman dan Kanuk (2010) mendefinisikan keputusan pembelian sebagai seleksi dari dua pilihan atau alternatif pilihan. Peter dan Olson (2009) menyatakan keputusan pembelian adalah sebuah proses yang menggabungkan pengetahuan untuk mengevaluasi dua atau lebih tindakan alternatif dan memilih salah satunya. 
Dari seluruh definisi di atas, maka dapat ditarik kesimpulan bahwa keputusan pembelian adalah tindakan yang dilakukan oleh seseorang untuk membeli atau tidak membeli suatu barang atau jasa berdasarkan pada evaluasi dan pengetahuannya.

\section{Kaitan antara kualitas produk dengan keputusan pembelian}

Waluya dan Iqbal (2019) melakukan penelitian tentang pelanggan otomotif di Indonesia dan dari penelitian tersebut didapatkan hasil bahwa kualitas produk berpengaruh terhadap keputusan pembelian. Jika industri membuat produk yang baik, maka pelanggan akan membuat keputusan pembelian. Peneltian yang dilakukan oleh Putro dan Nurmahdi (2020) tentang Honda Beat di Tangerang mendapatkan hasil bahwa kualitas produk berpengaruh secara signifikan terhadap keputusan pembelian. Hal tersebut sejalan dengan penelitian sebelumnya yang dilakukan oleh Ali dan Hapzi (2018) bahwa kualitas produk mempengaruhi keputusan pembelian. Ida dan Hidayanti (2014) meneliti tentang shampo Sariayu hijab di STAIN Kediri dan mendapatkan hasil bahwa kualitas produk mempengaruhi keputusan pembelian.

\section{Kaitan antara citra merek dan keputusan pembelian}

Djatmiko dan Pradana (2015) melakukan penelitian tentang Smartphone Samsung dan mendapatkan hasil bahwa terdapat pengaruh citra merek terhadap keputusan pembelian. Jika citra merek yang dimiliki oleh suatu produk baik, maka akan tingkat keputusan pembelian tinggi. Penelitian yang dilakukan oleh Saridewi, et al. (2020) tentang shampo Pantene di Surabaya mendapatkan hasil penelitian bahwa citra merek memiliki pengaruh yang signifikan terhadap keputusan pembelian. Semakin kuat citra merek dalam benak pelanggan, maka semakin kuat keinginan untuk bersikap loyal terhadap produk tersebut. Wedangga dan Keni (2020) meneliti tentang pengguna produk kecantikan di Jakarta dan Tangerang mendapatkan hasil bahwa citra merek berpengaruh terhadap keputusan pembelian. Artinya Citra merek baik yang dimiliki oleh suatu perusahaan akan meyakinkan sesorang untuk membeli barang tersebut.

\section{Kaitan antara Persepsi Harga dan Keputusan Pembelian}

Anwar dan Andrean (2020) melakukan penelitian tentang pembelian tiket pesawat pada situs traveloka.com di Yogyakarta dan mendapatkan hasil bahwa persepsi harga berpengaruh terhadap keputusan pembelian. Hasil penelitian tersebut sejalan dengan penelitian sebelumnya yang dilakukan oleh Muharam dan Soliha (2017) bahwa persepsi harga secara positif mempengaruhi keputusan pembelian. Oscar dan Keni (2019) meneliti tentang konsumen donat di Jakarta dan hasil penelitiannya adalah persepsi harga berpengaruh terhadap keputusan pembelian. Persepsi harga berperan penting dalam keputusan pembelian apakah produk yang diperoleh sesuai dengan harga yang dibayarkan. Penelitian yang dilakukan oleh Widyastutir dan Said (2017) tentang sepatu olahraga SPECS di Indonesia mendapatkan hasil bahwa persepsi harga berpengaruh secara signifikan terhadap keputusan pembelian. Semakin baik seorang pelanggan dapat menerima harga suatu barang, semakin cepat keputusan untuk membeli barang tersebut.

Berdasarkan uraian kaitan antara variabel-variabel penelitian di atas, maka model penelitian adalah sebagai berikut: 


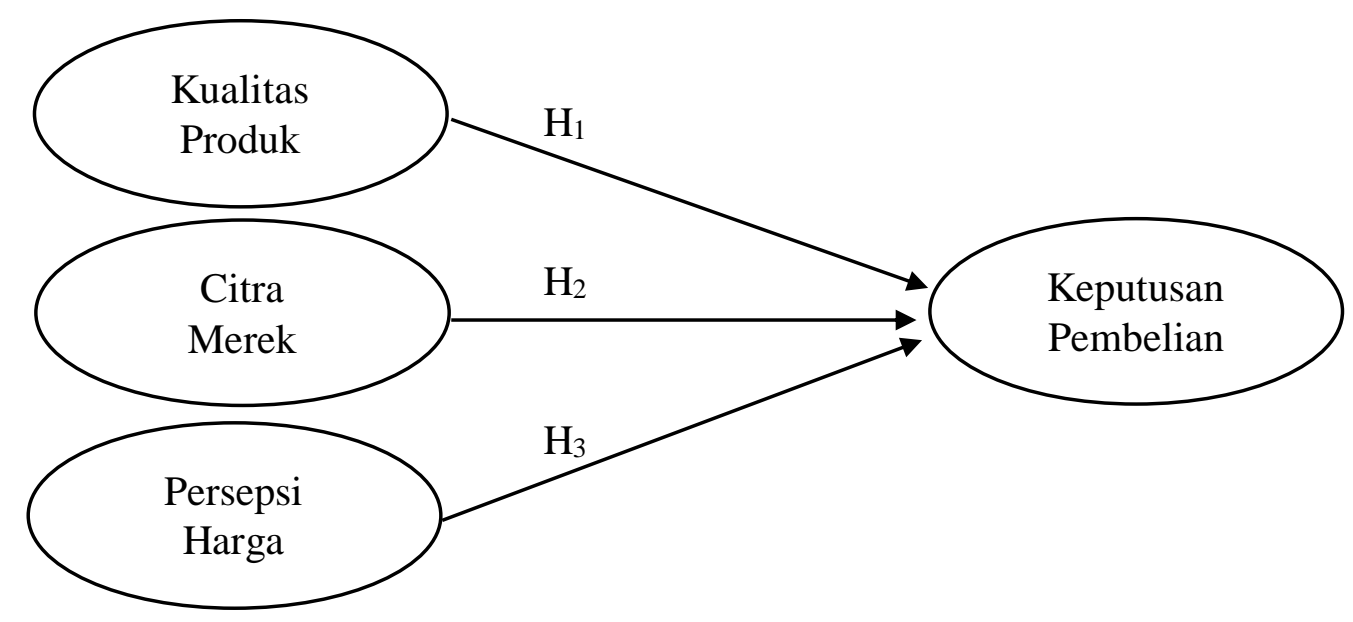

Gambar 1. Hubungan antar Variabel

\section{METODOLOGI}

Penelitian ini merupakan penelitian deskriptif dan pendekatan cross-sectional dengan variabel penelitian berupa kualitas produk, citra merek, dan persepsi harga. Sampel dalam penelitian ini sebanyak 100 responden yang merupakan pengguna masker Sensi di Tangerang. Metode yang digunakan dalam penelitian ini adalah non probability sampling dengan teknik purposive sampling dimana pemilihan populasi untuk dijadikan sampel terbatas pada orang tertentu, dipilih berdasarkan pada kriteria responden yang telah ditetapkan.

Berdasarkan data yang telah dikumpulkan, responden dalam penelitian ini berjenis kelamin pria 52\% dan wanita 48\%. Berdasarkan usia 17-21 tahun 33\%, 22-26 tahun 58\%, 2731 tahun 5\%, dan berusia lebih dari 32 tahun 4\%. Berdasarkan perpendidikan terakhir Sekolah Menengah Pertama 1\%, Sekolah Menengah Atas (SMA) 53\%, S1/S2/S3 44\%, dan lainnya 2\%, yaitu D1 dan D3. Berdasarkan pekerjaan seorang pelajar/mahasiswa $48 \%$, Karyawan/karyawati $32 \%$, Ibu rumah tangga $2 \%$, wirausahawan $14 \%$, dan lainnya $4 \%$. Berdasarkan melakukan pembelian atas masker sensi 1 kali dalam sebulan 37\%, 2-3 kali dalam sebulan $45 \%$, lebih dari 3 kali sebulan $18 \%$. Berdasarkan pengeluaran uang atas pembelian masker sensi sebanyak kurang dari Rp 100.000 dalam sebulan 48\%, Rp 100.000-300.000 44\%, dan lebih dari Rp 300.000 sebanyak $8 \%$.

Dalam mengukur variabel penelitian, skala pengukuran diukur menggunakan skala Likert 1-5 dengan 1 menunjukkan "sangat tidak setuju" dan 5 menunjukkan "sangat setuju". Pengujian instrumen menggunakan pengujian model pengukuran (outer model analysis) yang digunakan untuk mengukur validitas dan reliabilitas. Pengujian validitas dilihat pada nilai Average Variance Extracted (AVE) dan cross loading factor. Pada pengujian reliabilitas dilihat pada nilai composite reliabily dan cronbach's alpha.

Berdasarkan uji validitas yang telah dilakukan, nilai AVE pada penelitian ini memiliki nilai lebih dari 0,5 dan pada pengujian cross loading factor setiap indikator memiliki nilai yang lebih tinggi dibandingkan dengan indikator konstruk lainnya. Pada uji reliabilitas nilai composite reliability lebih besar dari 0.7 dan nilai cronbach's alpha lebih besar dari 0.6. Sehingga dapat diketahui bahwa setiap indikator dalam penelitian ini valid dan reliabel. 
Penelitian ini dilakukan dengan menyebarkan kuesioner dalam bentuk googleform secara daring melalui sosial media. Dalam melakukan pengujian penelitian ini menggunakan bantuan perangkat lunak SmartPLS.

Tabel 1. Variabel dan Pengukuran

\begin{tabular}{|c|c|c|c|}
\hline Variabel & Jumlah Indikator & Skala & Sumber \\
\hline $\begin{array}{l}\text { Variabel Eksogen: } \\
\text { 1. Kualitas Produk } \\
\text { 2. Citra Merek } \\
\text { 3. Persepsi Harga }\end{array}$ & $\begin{array}{c}38 \\
6\end{array}$ & $\begin{array}{l}\text { Ordinal } \\
\text { Ordinal } \\
\text { Ordinal }\end{array}$ & 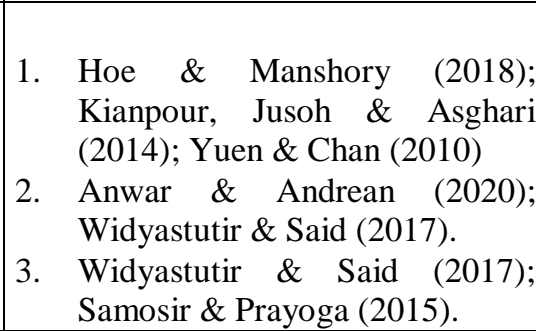 \\
\hline $\begin{array}{l}\text { Variabel Endogen: } \\
\text { Keputusan Pembelian }\end{array}$ & 4 & Ordinal & $\begin{array}{l}\text { Anwar \& Andrean (2020); Suhaily } \\
\text { \& Darmoyo (2017). }\end{array}$ \\
\hline
\end{tabular}

\section{HASIL ANALISIS DATA}

\section{Validitas}

a. Convergent Validity

Tabel 2. Hasil Average Variance Extracted

\begin{tabular}{|l|c|}
\hline \multicolumn{1}{|c|}{ Variabel / Dimensi } & Average Variance Extracted \\
\hline Keputusan Pembelian & 0.667 \\
\hline Kualitas Produk & 0.512 \\
\hline Conformance & 0.670 \\
\hline Performance & 0.734 \\
\hline Durability & 0.775 \\
\hline Reliability & 0.771 \\
\hline Features & 0.653 \\
\hline Serviceability & 0.754 \\
\hline Aesthetic & 0.764 \\
\hline Perceived Quality & 0.854 \\
\hline Citra Merek & 0.629 \\
\hline Persepsi Harga & 0.631 \\
\hline
\end{tabular}

Dapat diketahui berdasarkan tabel 2 di atas menyatakan bahwa nilai AVE dari semua variabel memiliki nilai lebih dari 0,50 (>0.50). Mengartikan bahwa seluruh variabel telah valid dan dapat diikut sertakan dalam penelitian. 
b. Discriminant Validity

Tabel 3. Hasil Nilai Cross Loading Factor

\begin{tabular}{|c|c|c|c|c|}
\hline & $\begin{array}{c}\text { Kualitas } \\
\text { Produk }\end{array}$ & Citra Merek & Persepsi Harga & $\begin{array}{l}\text { Keputusan } \\
\text { Pembelian }\end{array}$ \\
\hline PQ1 & 0.647 & 0.521 & 0.307 & 0.465 \\
\hline$\overline{\mathrm{PQ} 2}$ & 0.625 & 0.426 & 0.358 & 0.448 \\
\hline PQ3 & 0.736 & 0.585 & 0.388 & 0.530 \\
\hline PQ4 & 0.643 & 0.544 & 0.368 & 0.547 \\
\hline PQ5 & 0.698 & 0.704 & 0.411 & 0.601 \\
\hline PQ6 & 0.756 & 0.636 & 0.433 & 0.575 \\
\hline PQ7 & 0.629 & 0.496 & 0.488 & 0.483 \\
\hline PQ8 & 0.635 & 0.543 & 0.407 & 0.503 \\
\hline PQ9 & 0.732 & 0.560 & 0.475 & 0.594 \\
\hline PQ10 & 0.785 & 0.627 & 0.557 & 0.655 \\
\hline PQ11 & 0.799 & 0.625 & 0.518 & 0.619 \\
\hline PQ12 & 0.736 & 0.628 & 0.515 & 0.596 \\
\hline PQ13 & 0.724 & 0.673 & 0.409 & 0.563 \\
\hline PQ14 & 0.781 & 0.654 & 0.600 & 0.650 \\
\hline PQ15 & 0.749 & 0.598 & 0.579 & 0.639 \\
\hline PQ16 & 0.629 & 0.528 & 0.375 & 0.440 \\
\hline PQ17 & 0.664 & 0.474 & 0.364 & 0.432 \\
\hline PQ18 & 0.687 & 0.466 & 0.400 & 0.432 \\
\hline PQ19 & 0.635 & 0.484 & 0.462 & 0.566 \\
\hline PQ20 & 0.728 & 0.521 & 0.571 & 0.592 \\
\hline PQ21 & 0.770 & 0.595 & 0.593 & 0.628 \\
\hline PQ22 & 0.760 & 0.695 & 0.579 & 0.733 \\
\hline$\overline{\text { PQ23 }}$ & 0.778 & 0.624 & 0.548 & 0.676 \\
\hline PQ24 & 0.803 & 0.667 & 0.470 & 0.624 \\
\hline BI1 & 0.477 & 0.707 & 0.262 & 0.468 \\
\hline BI2 & 0.691 & 0.847 & 0.435 & 0.636 \\
\hline BI3 & 0.783 & 0.887 & 0.600 & 0.760 \\
\hline BI4 & 0.503 & 0.696 & 0.353 & 0.444 \\
\hline BI5 & 0.667 & 0.865 & 0.559 & 0.707 \\
\hline BI6 & 0.643 & 0.735 & 0.596 & 0.694 \\
\hline PP1 & 0.591 & 0.562 & 0.863 & 0.721 \\
\hline PP2 & 0.661 & 0.748 & 0.881 & 0.818 \\
\hline PP3 & 0.377 & 0.171 & 0.684 & 0.408 \\
\hline PP4 & 0.381 & 0.249 & 0.732 & 0.469 \\
\hline PD1 & 0.733 & 0.773 & 0.713 & 0.901 \\
\hline PD2 & 0.495 & 0.373 & 0.524 & 0.647 \\
\hline PD3 & 0.690 & 0.696 & 0.707 & 0.857 \\
\hline PD4 & 0.665 & 0.702 & 0.657 & 0.839 \\
\hline
\end{tabular}


Dari tabel 3 dapat dilihat bahwa indikator dari setiap konstruk memiliki nilai yang lebih tinggi dibandingkan dengan indikator konstruk lainnya. Mengartikan bahwa seluruh indikator penyusun setiap variabel laten dalam penelitian ini telah memenuhi discriminant validity.

Tabel 4. Fornell Larcker Criterion

\begin{tabular}{|l|c|c|c|c|}
\hline & $\begin{array}{c}\text { Citra } \\
\text { Merek }\end{array}$ & $\begin{array}{c}\text { Keputusan } \\
\text { Pembelian }\end{array}$ & $\begin{array}{c}\text { Persepsi } \\
\text { Harga }\end{array}$ & $\begin{array}{c}\text { Kualitas } \\
\text { Produk }\end{array}$ \\
\hline Citra Merek & $\mathbf{0 . 8 2 7}$ & & & \\
\hline $\begin{array}{l}\text { Keputusan } \\
\text { Pembelian }\end{array}$ & 0.748 & $\mathbf{0 . 8 0 6}$ & & \\
\hline Persepsi Harga & 0.625 & 0.786 & $\mathbf{0 . 7 9 5}$ & \\
\hline Kualitas Produk & 0.737 & 0.773 & 0.647 & $\mathbf{0 . 7 8 8}$ \\
\hline
\end{tabular}

Berdasarkan tabel 4 di atas dapat diketahui bahwa seluruh variabel memiliki nilai yang lebih tinggi dibanding dengan nilai variabel lainnya. Citra merek memiliki nilai 0.827 yang lebih tinggi dibandingkan dengan nilai variabel lain pada kolom yang sama. Kualitas produk pun memiliki nilai 0.788 yang nilainya lebih tinggi dibandingkan dengan citra merek, keputusan pembelian, dan persepsi harga yang berada pada kolom yang sama

\section{Reliabilitas}

Tabel 5. Nilai Composite Reliability dan Cronbach's alpha

\begin{tabular}{|l|c|c|}
\hline \multicolumn{1}{|c|}{ Variabel / Dimensi } & Composite Reliability & Cronbach's Alpha \\
\hline Keputusan Pembelian & 0.887 & 0.829 \\
\hline Kualitas Produk & 0.960 & 0.956 \\
\hline Conformance & 0.859 & 0.754 \\
\hline Performance & 0.892 & 0.820 \\
\hline Durability & 0.912 & 0.853 \\
\hline Reliability & 0.910 & 0.850 \\
\hline Features & 0.850 & 0.735 \\
\hline Serviceability & 0.901 & 0.834 \\
\hline Aesthetic & 0.906 & 0.844 \\
\hline Perceived Quality & 0.946 & 0.914 \\
\hline Citra Merek & 0.910 & 0.881 \\
\hline Persepsi Harga & 0.871 & 0.814 \\
\hline
\end{tabular}

Berdasarkan tabel 5 dapat dilihat nilai composite reliability memiliki nilai di atas $0.7(>0.7)$ dan cronbach's alpha memiliki nilai di atas $0.6(>0.6)$ sehingga dapat disimpulkan bahwa seluruh konstruk reliabel. 


\section{Hasil Pengujian Hipotesis}

Berikut adalah hasil analisis data yang disajikan secara singkat:

Tabel 6. Hasil Path Coefficient, T-statistic, dan P-value

\begin{tabular}{|c|l|c|c|c|}
\hline & \multicolumn{1}{|c|}{ Hipotesis } & Path Coefficient & T-Statistics & P-value \\
\hline $\mathrm{H}_{1}$ & $\begin{array}{l}\text { Kualitas Produk } \rightarrow \text { Keputusan } \\
\text { Pembelian }\end{array}$ & 0.230 & 2.495 & 0.013 \\
\hline $\mathrm{H}_{2}$ & Citra merek $\rightarrow$ Keputusan Pembelian & 0.343 & 3.604 & 0.000 \\
\hline $\mathrm{H}_{3}$ & $\begin{array}{l}\text { Persepsi Harga } \rightarrow \text { Keputusan } \\
\text { Pembelian }\end{array}$ & 0.440 & 5.313 & 0.000 \\
\hline
\end{tabular}

Berdasarkan hasil uji hipotesis yang terdapat pada tabel 6 dapat diketahui bahwa kualitas produk memiliki pengaruh positif dan signifikan. Hal ini dapat dilihat dari nilai $t$ statistic sebesar 2.495 dan nilai $p$-value 0.013. Citra merek memiliki pengaruh positif dan signifikan yang dapat dilihat dari nilai $t$-statistic sebesar 3.604 dan nilai $p$-value 0.000 . Persepsi harga memiliki pengaruh yang positif dan signifikan yang dapat dilihat dari nilai nilai $t$-statistic sebesar 5.313 dan nilai $p$-value 0.000. Dapat diketahui dari hasil nilai path coefficient variabel persepsi harga memberikan pengaruh positif yang paling besar terhadap keputusan pembelian dibanding variabel kualitas produk dan citra merek.

\section{DISKUSI}

Hasil penelitian ini sejalan dengan penelitian sebelumnya yang dilakukan oleh Waluya dan Iqbal (2019), Nurmahdi (2020), serta Ida dan Hidayanti (2014) yang menyatakan bahwa kualitas produk berpengaruh positif terhadap keputusan pembelian. Jika suatu produk memiliki kualitas yang baik dan mampu memenuhi dimensi kualitas produk, maka seseorang akan cenderung melakukan pembelian atas produk tersebut.

Pada hipotesis yang kedua, hasil penelitian ini pun sejalan dengan penelitian sebelumnya yang dilakukan oleh Djatmiko dan Pradana (2015), Dewi, Edyanto, dan Siagian (2020), serta Hafilah, Chaer, dan Usman yang menyatakan bahwa citra merek berpengaruh positif terhadap keputusan pembelian. Citra merek sangat lah penting, citra merek yang baik akan menimbulkan keyakinan dalam diri seseorang untuk menggunakan produk tersebut. Produk yang memiliki citra bahwa produknya sesuai dengan standar yang telah ditetapkan secara luas akan dipilih untuk dibeli dibandingkan dengan produk yang tidak memiliki citra yang baik.

Demikian dengan hipotesis ketiga, hasil pada penelitian ini sesuai dengan penelitian yang dilakukan oleh Anwar dan Andrean (2020), Bnu, et al. (2018), serta Widyastutir dan Said (2017) yang menyatakan bahwa persepsi harga berpengaruh positif terhadap keputusan pembelian. Harga merupakan salah satu faktor pertimbangan seseorang dalam menentukan pembelian. Harga yang dirasa cukup mahal akan membuat seseorang enggan membeli produk tersebut dan cenderung memilih produk lain yang dirasa harganya sesuai dengan kemampuan orang tersebut. Dengan harga yang terjangkau dan manfaat yang sesuai akan meningkatkan keputusan pembelian seseorang terhadap produk tersebut. 


\section{KESIMPULAN}

Penelitian ini bertujuan untuk mengetahui pengaruh kualitas produk, citra merek, dan persepsi haga terhadap keputusan pembelian. Dari hasil pengujian yang telah dilakukan pada penelitian ini didapatkan hasil bahwa kualitas produk, citra merek, dan persepsi harga memiliki pengaruh yang positif dan signifikan terhadap keputusan pembelian masker Sensi di Tangerang.

Saran bagi peneliti selanjutnya yang akan meneliti tentang keputusan pembelian diharapkan untuk menambahkan variabel bebas lainnya sehingga penelitian ini dapat lebih berkembang dan bermanfaat. Kemudian peneliti selanjutnya dapat memperluas jangkauan wilayah penelitian dan menambah jumlah sampel agar data yang dihasilkan dari penelitian dapat menjelaskan kondisi lapangan yang sebenarnya.

Kemudian disarankan bagi produsen masker Sensi untuk mempertahankan dan meningkatkan kualitas produknya, agar dapat menjadi pilihan pertama konsumen saat akan menggunakan masker. Cara yang dapat dilakukan adalah dengan terus berinovasi atas kualitas produk seperti lapisan masker yang memudahkan untuk bernafas tanpa mengurangi fungsi dari masker tersebut, bahan tali masker yang tetap nyaman di telinga saat digunakan dalam jangka waktu yang panjang. Produk yang memiliki kualitas rendah akan membuat konsumen lebih memilih untuk menggunakan produk lain dengan kualitas yang lebih baik. Kemudian produsen masker Sensi disarankan untuk mempertahankan citra merek Sensi. Cara yang dapat dilakukan dengan melakukan promosi yang efektif bahwa masker Sensi merupakan masker yang memenuhi standar kesehatan dan membuat logo Sensi mudah untuk dikenali masyarakat. Selanjutnya, produsen masker Sensi disarankan untuk mempertahankan persepsi harga agar para pengguna masker Sensi merasa bahwa harga yang dibayarkan sesuai dengan kualitas dan manfaat yang dirasakan. Pemberian potongan harga berbatas waktu akan meningkatkan keputusan pembelian atas suatu produk.

\section{DAFTAR PUSTAKA}

Anwar, M., \& Andrean, D. (2021). The Effect of Perceived Quality, Brand Image, and Price Perception on Purchase Decision. Proceedings of the 4th International Conference on Sustainable Innovation 2020-Accounting and Management (ICoSIAMS 2020), 176(ICoSIAMS 2020), 78-82. https://doi.org/10.2991/aer.k.210121.012

Bei, L. T., \& Chiao, Y. C. (2006). The determinants of customer loyalty: An analysis of intangibile factors in three service industries. International Journal of Commerce and Management, 16(3-4), 162-177. https://doi.org/10.1108/10569210680000215

Campbell, M. C. (1999). Perceptions of Price Unfairness: Antecedents and Consequences. Journal of Marketing Research, 36(2), 187-199. https://doi.org/10.1177/002224379903600204

Čater, T., \& Čater, B. (2010). Product and relationship quality influence on customer commitment and loyalty in B2B manufacturing relationships. Industrial Marketing Management, 39(8), 1321-1333. https://doi.org/10.1016/j.indmarman.2010.02.006

Cooper, D. R., \& Schindler, P. S. (2013). Business Research Methods 12th Edition. New York: McGraw-Hill.

Djatmiko, T., \& Pradana, R. (2016). Brand Image and Product Price; Its Impact for Samsung Smartphone Purchasing Decision. Procedia - Social and Behavioral Sciences, 219, 221227. https://doi.org/10.1016/j.sbspro.2016.05.009 
Fatmawati, N., \& Soliha, E. (2017). Kualitas Produk, Citra Merek dan Persepsi Harga Terhadap Proses Keputusan Pembelian Konsumen Sepeda Motor Matic "Honda." Jurnal Manajemen Teori Dan Terapan | Journal of Theory and Applied Management, 10(1), 1. https://doi.org/10.20473/jmtt.v10i1.5134

Garvin, D. A. (1984). Product quality: An important strategic weapon. Business Horizons, 27(3), 40-43. https://doi.org/10.1016/0007-6813(84)90024-7

Ghozali, I. (2016). Aplikasi Analisis Multivariate dengan SPSS. Semarang: Badan Penerbit Universitas Diponegoro.

Hafilah, N. E., Chaer, V.P., \& Usman, O. (2019). The Effect of Brand Ambassador, Brand Image, Product Quality, and Price on Purchase Decisions Samsung Smartphones. https://doi.org./10.16309/J.Ckni.Issn.10071776.2003.03.004

Hair, J. F., Sarstedt, M., Hopkins, L., \& Kuppelwieser, V. G. (2014). Partial least squares structural equation modeling (PLS-SEM): An emerging tool in business research. European Business Review, 26(2), 106-121. https://doi.org/10.1108/EBR-10-2013-0128

Hoe, L. C., \& Mansori, S. (2018). The Effects of Product Quality on Customer Satisfaction and Loyalty: Evidence from Malaysian Engineering Industry. International Journal of Industrial Marketing, 3(1), 20. https://doi.org/10.5296/ijim.v3i1.13959

Ida, Z., \& Hidayati, I. N. (2020). Brand Image and Product Quality Against Purchase Decision: Sariayu hijab shampoo competitive environment. IOP Conference Series: Earth and Environmental Science, 469(1). https://doi.org/10.1088/1755-1315/469/1/012109

Kianpour, K., Jusoh, A., \& Asghari, M. (2014). Environmentally friendly as a new dimension of product quality. International Journal of Quality and Reliability Management, 31(5), 547-565. https://doi.org/10.1108/IJQRM-06-2012-0079

Kotler, P. (2002). Marketing Management, Milenium Edition 10th Edition. Pearson Custom Publishing.

Kotler, P., \& Armstrong, G. (2011). Principles of Marketing. Pearson Prentice Hall.

Kotler, P., \& Keller, K. L. (2012). Marketing Management 14th Edition. New Jersey: Prentice Hall.

Malhotra, N. K. (2015). Essentials of Marketing Research. Pearson Education.

Oscar, Y., \& Keni, K. (2019). Pengaruh Brand Image, Persepi Harga, Dan Service Quality Terhadap Keputusan Pembelian Konsumen. Jurnal Muara Ilmu Ekonomi Dan Bisnis, 3(1), 20. https://doi.org/10.24912/jmieb.v3i1.3300

Peter, J. P., \& Olson, J. C. (2009). Consumer Behavior \& Marketing Strategy 9th Edition. New York: McGraw-Hill.

Putri, N. A., Ahmad, B., \& Sarsono. (2021). Citra Merek, Kepercayaan Merek, dan Kualitas Produk Terhadap Keputusan Pembelian Hand Sanitizer Dettol Pada Masa Pandemi Covid-19 di Luwes Gentan. Jurnal Ekbis, 22(1), 69-87. https://doi.org/10.30736\%2Fje.v22i1.698

Putro, C. H., \& Nurmahdi, A. (2020). Analysis of Purchase Decision and its Impacts towards Honda Beat Motorcycle's Customer Satisfaction Viewed through Product Quality and Price Perception Variables at Tangerang City Area. International Journal of Innovative Science and Research Technology, 5(6), 1222-1229. https://doi.org/10.38124/ijisrt20jun1012

Rommy, A. S. N., Moh, N. B. H. H., \& Nur, A. R. Y. N. (2018). Effect of Brand Image and Price Perception on Purchase Decision. Journal of Business and Management, 20(8), 7681. https://doi.org/10.9790/487X-2008027681 
Samosir, C. B. H., \& Prayoga, A. B. (2015). Pengaruh Persepsi Harga dan Promosi terhadap Keputusan Pembelian Konsumen Produk Enervon-C. Jurnal Ilmiah Manajemen Dan Bisnis, 1(November), 1-13.

Sari Dewi, L. G. P., Edyanto, N., \& Siagian, H. (2020). The Effect of Brand Ambassador, Brand Image, and Brand Awareness on Purchase Decision of Pantene Shampoo in $\begin{array}{lllll}\text { Surabaya, Indonesia. SHS Web of Conferences, 76, } 01023 . & .\end{array}$ https://doi.org/10.1051/shsconf/20207601023

Schiffman, L. G., \& Kanuk, L. L. (2010). Consumer behavior 10th edition. New Jersey: Pearson.

Solidaritas.net. (2020, Juni 30). PT. Arista Latindo, from https://solidaritas.net/pt-aristalatindo/

Suhaily, L., \& Darmoyo, S. (2017). Effect of product quality, perceived price and brand image on purchase decision mediated by customer trust (study on japanese brand electronic product). Jurnal Manajemen, 21(2), 179-194. https://doi.org/10.24912/jm.v21i2.230

Ulaga, W. (2003). Capturing value creation in business relationships: A customer perspective. Industrial Marketing Management, 677-693. https:doi.org/10.1016/j.indmarman.2003.06.008

Waluya, A. I., Iqbal, M. A., \& Indradewa, R. (2019). How product quality, brand image, and customer satisfaction affect the purchase decisions of Indonesian automotive customers. International Journal of Services, Economics and Management, 10(2), 177-193. https://doi.org/10.1504/IJSEM.2019.100944

Wedangga, I. G., \& Keni. (2020). Brand Image danCountry of Origin Untuk Memprediksi Purchase Decision Konsumen: Variabel Perceived Quality Sebagai Variabel Mediasi. Jurnal Manajemen Bisnis dan Kewirausahaan, 276-281.

Widyastutir, S., \& Said, M. (2017). Consumer consideration in purchase decision of SPECS sports shoes product through brand image, product design and price perception. International Journal of Supply Chain Management, 6(4), 199-207.

Yuen, E. F. T., \& Chan, S. S. L. (2010). The effect of retail service quality and product quality on customer loyalty. Journal of Database Marketing and Customer Strategy Management, 17(3-4), 222-240. https://doi.org/10.1057/dbm.2010.13

Zietsman, M. L., Mostert, P., \& Svensson, G. (2019). Perceived price and service quality as mediators between price fairness and perceived value in business banking relationships: A micro-enterprise perspective. International Journal of Bank Marketing, 37(1), 2-19. https://doi.org/10.1108/IJBM-07-2017-0144 